\title{
KEKUATAN GESER SHEAR KEY PADA JEMBATAN SEGMENTAL BOX GIRDER BENTANG PANJANG
}

\author{
Claudia Chandra' ${ }^{1}$ dan F.X. Supartono ${ }^{2}$ \\ ${ }^{1}$ Program Studi Sarjana Teknik Sipil, Universitas Tarumanagara, Jl. Letjen S. Parman No.1 Jakarta \\ Email: claudiachandra2309@gmail.com \\ ${ }^{2}$ Program Studi Sarjana Teknik Sipil, Universitas Tarumanagara, Jl. Letjen S. Parman No.1 Jakarta \\ Email:fxsupartono@gmail.com
}

\begin{abstract}
ABSTRAK
Shear key adalah komponen dari struktur jembatan segmental box girder yang berperan menyalurkan gaya geser dari satu segmen ke segmen lainnya. Ada beberapa jenis shear key yang dapat digunakan untuk sambungan antara segmen box girder yaitu flat key, single shear key dan multiple shear key. Sambungan ini bisa berupa sambungan basah (wet joint) atau sambungan kering (dry joint). Sambungan basah berupa zat perekat yang berfungsi untuk merekatkan antara segmen. Beberapa jenis perekat yang biasa digunakan di sambungan ini yaitu non-shrink grout, epoxy, magnesium ammonium nitrate mortar dan beton polimer. Apabila menggunakan perekat maka perekat yang dioleskan pada sambungan masih dalam kondisi plastik dan hanya berfungsi sebagai pelumas yang mengurangi koefisien gesekan antara segmen. Pada jurnal ini jenis shear key yang akan dibahas adalah single shear key dan multiple shear key pada web box girder. Penelitian ini bertujuan untuk membandingkan kapasitas geser nominal antara single shear key dan multiple shear key serta pengaruh ukuran dan sudut shear key terhadap kapasitas geser. Hasil penelitian menunjukkan peningkatan kapasitas geser pada web box girder setelah penggunaan shear key. Multiple shear key memiliki kapasitas geser nominal yang lebih besar daripada single shear key dan penggunaan epoxy menyebabkan penurunan kapasitas geser nominal pada web box girder. Kapasitas geser nominal dari shear key juga dipengaruhi oleh besarnya sudut dan tinggi shear key.
\end{abstract}

Kata kunci: kapasitas geser, sudut shear key, tinggi shear key, epoxy

\section{PENDAHULUAN}

Indonesia menduduki urutan keempat negara dengan jumlah penduduk terbesar di dunia. Setiap tahun jumlah penduduk ini semakin bertambah dan disertai dengan meningkatnya daya beli masyarakat terhadap kendaraan bermotor. Pertumbuhan kepemilikan kendaraan yang terus bertambah sementara infrastruktur jalanan yang belum memadai menimbulkan kemacetan. Pada pemerintahan dibawah kepemimpinan Presiden Joko Widodo, pembangunan infrastruktur menjadi prioritas pembangunan nasional. Salah satu proyek prioritas untuk memperlancar arus lalu lintas di Indonesia yaitu pembangunan jembatan. Pembangunan jembatan memberikan konektivitas antara wilayah yang dihubungkan. Beberapa tahun ini, perencanaan struktur jalan layang di Indonesia telah banyak menggunakan box girder dengan prinsip beton prategang. Kemampuan dan ketahanan sebuah jembatan dipengaruhi oleh jenis dan kekuatan girder.

Perencanaan sambungan antara segmen box girder merupakan hal yang perlu diperhatikan. Sambungan kunci geser (shear key) merupakan komponen sekunder dari struktur jembatan karena memiliki dimensi yang kecil dan biasanya diabaikan pengaruhnya terhadap jembatan. Sambungan ini berperan menyalurkan gaya geser dari satu segmen ke segmen lainnya dan menahan perpindahan lateral dari segmen box girder. Peranan penting dari shear key dalam menjaga ketahanan struktur jembatan tidak boleh diabaikan.

Dikarenakan kerusakan pada shear key dapat mengakibatkan kegagalan struktur jembatan, kontrol geser pada shear key harus dilakukan secara teliti agar mencegah terjadinya crack selama masa pelayanan. Besarnya beban yang dapat diterima bergantung pada jenis dan ukuran dari shear key. Dimensi daripada shear key akan berpengaruh terhadap kapasitas geser nominal yang bekerja. Pada penelitian ini digunakan jenis single shear key dan multiple shear key untuk dibandingkan besarnya gaya geser nominal pada sambungan segmental box girder. Beban vertikal yang bekerja pada sambungan akan ditransfer ke masing-masing elemen shear key untuk dilakukan pengecekan.

Rumusan masalah yang akan dibahas dalam tugas akhir ini adalah perbandingan kapasitas geser nominal single shear key dan multiple shear key serta pengaruh ukuran dan sudut shear key terhadap kapasitas geser nominal 
dengan menggunakan metode AASHTO, ATEP, hasil penelitian Prof. Dr. Ing. G. Rombach dan hasil penelitian Turmo.

\section{Beton prategang}

Beton prategang terdiri dari beberapa material yaitu beton, baja prategang, grouting dan selongsong. Pada beton ini, baja prategang digunakan untuk memberikan tegangan tekan pada beton. Material beton prategang terdiri dari beton, baja prategang, grouting, dan selongsong (duct). Menurut Nawy (2001) menyatakan bahwa pada balok prategang, balok diasumsikan bersifat homogen dan elastis. Ketidakmampuan beton untuk menahan tegangan tarik, digantikan oleh tegangan tekan yang diakibatkan oleh tendon prategang.

\section{Kehilangan prategang}

Kehilangan prategang adalah berkurangnya gaya yang bekerja pada tendon dalam tahap-tahap pembebanan baik akibat penarikan baja prategang maupun akibat pengruh waktu. Kehilangan prategang pada struktur beton prategang diilustrasikan pada gambar 1 di bawah ini.

$$
\begin{aligned}
& \mathrm{P}_{\mathrm{j}} \underset{\text { (Immediate Losses) }}{\stackrel{\text { Kehilangan Langsung }}{\longrightarrow}} \mathrm{P}_{\mathrm{i}} \underset{\text { (Time Dependent Losses) }}{\stackrel{\text { Kehilangan Tergantung Waktu }}{\longrightarrow}} \mathrm{P}_{\mathrm{e}} \\
& \begin{array}{ccc}
\text { Gaya Prategang } & \text { Gaya Prategang Sesaat } & \text { Gaya Prategang } \\
\text { Awal } & \text { Setelah Transfer } & \text { Akhir/Efektif }
\end{array} \\
& \text { (Jacking Force) (Initial Force) (Final/Effective Force) }
\end{aligned}
$$

Gambar 1. Ilustrasi Kehilangan Gaya Prategang (Sumber: Rizkia, 2017)

Berdasarkan SNI 2847:2013, sumber-sumber kehilangan prategang dalam menentukan tegangan efektif dalam baja prategang meliputi dudukan baja prategang saat penyaluran, perpendekan elastis beton, rangkak beton, susut beton, relaksasi tegangan baja prategang dan kehilangan friksi akibat kurvatur sengaja atau tidak sengaja pada tendon pasca-tarik.

Saat penarikan tendon pada struktur pasca-tarik terjadi gesekan antara beton dan tendon prategang yang mengakibatkan kehilangan gaya prategang sepanjang bentang. Gesekan ini dipengaruhi oleh kelengkungan tendon dan komponen vertikal dari gaya prategang seperti pada gambar 2 dibawah ini.

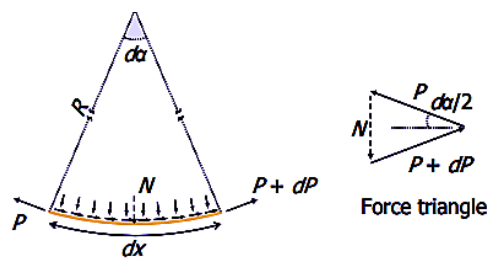

Gambar 2. Gaya Prategang Bekerja pada Tendon Lengkung (Sumber: Prestressed Concrete Structures)

Kehilangan gaya prategang akibat gesekan tendon dapat dihitung menggunakan rumus 1 sebagai berikut:

$$
F_{p F}=F_{0} \cdot e^{-(\mu \alpha+k x)}
$$

dengan $F_{p F}=$ gaya prategang setelah kehilangan akibat gesekan tendon, $F_{0}=$ gaya prategang awal, $\mu=$ koefisien gesek kelengkungan, $\alpha=$ sudut kelengkungan tendon, dan $k=$ koefisien wobble.

Pada struktur pasca-tarik, saat penarikan tendon akan mengalami slip angkur saat tendon dilepaskan dari mesin penarik dan ditahan baji pada angkur. Blok angkur juga akan mengalami pergerakan sebelum menyatu dengan beton. Hal ini menyebabkan perpendekan tendon yang mengakibatkan adanya kehilangan gaya prategang seperti pada gambar 3 dibawah ini.

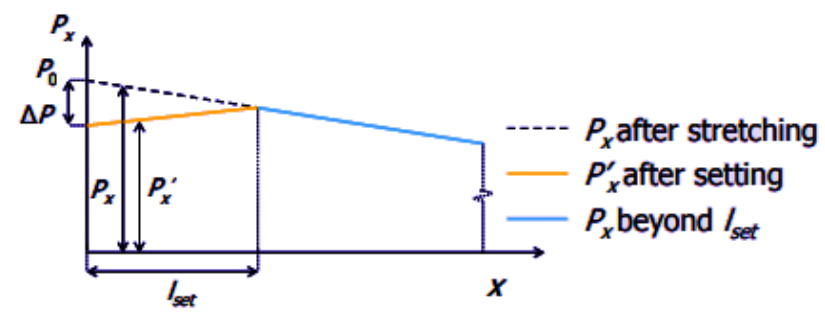

Gambar 3. Diagram Gaya Prategang di Sekitar Angkur Hidup (Sumber: Prestressed Concrete Structures) 
Besarnya slip angkur bergantung pada jenis atau sistem angkur yang digunakan. Data besarnya slip angkur yang digunakan pada tugas akhir diperoleh dari spesifikasi angkur VSL yaitu sebesar $7 \mathrm{~mm}$. Penentuan kehilangan prategang akibat slip angkur dihitung dengan menggunakan rumus 2 sampai 4 sebagai berikut:

$$
\begin{aligned}
\mathrm{F}_{0 \eta} & =\frac{\Delta F}{L} \\
\mathrm{~L}_{\text {set }} & =\sqrt{\frac{\Delta \mathrm{s} \times A_{p} \times E_{p}}{\mathrm{~F}_{0 \eta}}} \\
\Delta F_{p A} & =2 \times \mathrm{F}_{0 \eta} \times \mathrm{L}_{\text {set }}
\end{aligned}
$$

dengan $\mathrm{F}_{0 \eta}=$ kehilangan gaya prategang akibat friksi per satuan panjang, $\Delta F_{p A}=$ kehilangan gaya prategang akibat friksi, $\mathrm{L}=$ panjang bentang, dan $\mathrm{L}_{\mathrm{set}}=$ panjang bentang yang dipengaruhi oleh slip angkur.

Setelah gaya prategang ditransfer ke beton, beton akan mengalami perpendekan elastis yang akan mengakibatkan memendeknya baja prategang, hal ini akan menyebabkan berkurangnya gaya prategang. Pada metode pasca-tarik kehilangan gaya prategang sangat bergantung pada tahapan penarikan. Penentuan kehilangan prategang akibat perpendekan elastis dihitung dengan menggunakan rumus 5 sebagai berikut:

$$
\Delta F_{p E S}=m \times E S \times A_{p}
$$

dengan $\Delta F_{p E S}=$ kehilangan gaya prategang akibat perpendekan elastis, $\mathrm{m}=$ perbandingan nilai modulus elastisitas baja prategang dengan modulus elastisitas beton, dan $A_{p}=$ uas tendon.

Rangkak pada beton terjadi karena peningkatan deformasi terhadap waktu pada kondisi beban yang konstan. Rangkak akan mengakibatkan berkurangnya tegangan pada penampang. Besarnya kehilangan prategang akibat rangkak pada beton dapat dihitung menggunakan rumus 6 dibawah ini:

$$
\Delta F_{p C R}=m \times K_{c r} \times\left(f_{c s}-f_{c d s}\right)
$$

dengan $\Delta F_{p C R}=$ kehilangan gaya prategang akibat rangkak beton, $\mathrm{K}_{\mathrm{cr}}=1.60$ untuk komponen struktur pasca-tarik , $\mathrm{f}_{\mathrm{cs}}=$ tegangan beton pada titik berat tendon akibat berat sendiri box, dan $\mathrm{f}_{\mathrm{cds}}=$ tegangan beton pada titik berat tendon akibat beban mati tambahan.

Susut merupakan perubahan volume pada beton yang dipengaruhi oleh beberapa faktor. Faktor yang mengakibatkan susut beton meliputi proporsi campuran, tipe agregat, tipe semen, waktu perawatan, waktu antara akhir perawatan eksternal dan pemberian gaya prategang, ukuran komponen struktur dan kondisi lingkungan. Ada beberapa ketentuan untuk memperhitungkan kehilangan gaya prategang akibat susut, berikut ini adalah salah satu cara yang dapat digunakan sepert pada rumus 7 dan 8 dibawah ini:

$$
\begin{array}{ll}
\varepsilon_{\mathrm{sh}} & =\frac{0.0002}{\log (t+2)} \\
\Delta \mathrm{f}_{\mathrm{pSH}} & =E_{p} \times \varepsilon_{s h}
\end{array}
$$

dengan $\varepsilon_{\text {sh }}=$ regangan susut dalam beton, $\mathrm{t}=$ umur pembebanan,$\Delta \mathrm{f}_{p S H}=$ kehilangan gaya prategang akibat susut, dan $\mathrm{E}_{\mathrm{p}}=$ modulus elastisitas tendon.

Kehilangan gaya prategang akibat relaksasi baja terjadi karena adanya perpanjangan konstan dari baja prategang terhadap waktu. Besarnya penurunan gaya prategang tersebut tidak hanya bergantung pada durasi gaya prategang tersebut, tetapi juga dipengaruhi oleh rasio antara tegangan awal baja prategang dan kuat leleh baja prategang $\left(\frac{f_{p i}}{f_{p y}}\right)$.

Berdasarkan SNI 2847:2013 membatasi tegangan tarik untuk tendon pasca-tarik, pada daerah angkur dan sambungan sesaat setelah transfer gaya sebesar $0.70 \mathrm{f}_{\mathrm{pu}}$ dan nilai $\mathrm{f}_{\mathrm{py}}$ dapat dihitung dari:

- $\quad$ Batang prategang, $\mathrm{f}_{\mathrm{py}}=0.80 \mathrm{f}_{\mathrm{pu}}$

- $\quad$ Tendon stress relieved, $\mathrm{f}_{\mathrm{py}}=0.85 \mathrm{f}_{\mathrm{pu}}$

- $\quad$ Tendon relaksasi rendah, $\mathrm{f}_{\mathrm{py}}=0.90 \mathrm{f}_{\mathrm{pu}}$

Kehilangan gaya prategang akibat relaksasi dapat dihitung dengan menggunakan rumus 9 sebagai berikut:

$$
\Delta f_{p R}=f_{p i}^{\prime} \times\left(\frac{\log t}{10}\right) \times\left(\frac{f_{p i}^{\prime}}{f_{p y}}-0.55\right)
$$

dengan $\Delta f_{p R}=$ kehilangan gaya prategang akibat relaksasi baja, $f^{\prime}{ }_{p i}=$ tegangan tarik tendon sesaat setelah transfer gaya, dan $f_{p y}=$ kuat leleh baja prategang. 


\section{Shear key}

Pelaksanaan jembatan segmental box girder di lapangan dilakukan secara bertahap. Setiap segmen diangkat kemudian ditempatkan sesuai dengan posisi yang telah ditentukan. Shear key biasa terletak pada bagian web girder jembatan. Shear key memiliki dua fungsi yaitu untuk menyesuaikan antara segmen selama ereksi dan mentransfer kekuatan geser selama periode tersebut. Ada beberapa jenis sambungan geser yang dapat digunakan untuk menjadi sambungan antara segmen box girder. Sambungan ini bisa berupa sambungan basah (wet joint) dan sambungan kering (dry joint). Pada sambungan basah, sambungan diberikan zat perekat yang berfungsi untuk merekatkan antara satu bagian dengan bagian lainnya. Bentuk-bentuk sambungan geser dapat dibagi menjadi 3, yaitu sambungan datar (no key), single key, dan multiple keys (Koseki: 1983,4). Bentuk sambungan geser menurut Koseki seperti pada gambar 4 dibawah ini.

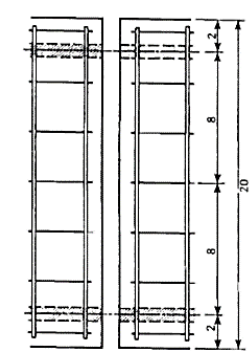

a) No-k

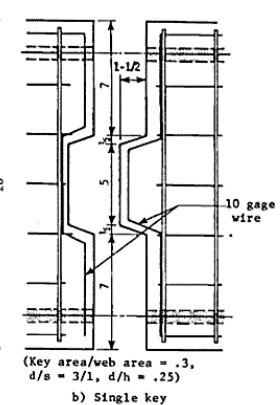

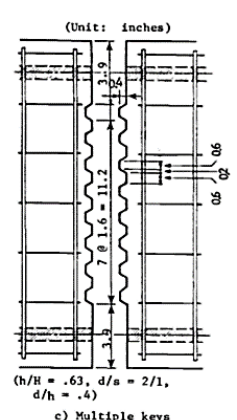

c) Multiple keys

Gambar 4. Bentuk-Bentuk Shear Key (Sumber: Koseki, 1983)

\section{Kapasitas geser pada shear key}

Desain shear key pada umumnya mengacu pada rumus yang dikeluarkan oleh American Association of State Highway and Transportation Officials (AASHTO). AASHTO menentukan kapasitas geser dari shear key dengan persamaan 10 sebagai berikut:

$$
V_{n}=A_{k} \sqrt{f_{c k}}\left(0.2048 \sigma_{n}+0.9961\right)+0.6 A_{s m} \sigma_{n}
$$

dengan $\mathrm{V}_{\mathrm{n}}=$ gaya geser nominal pada shear key, $\mathrm{A}_{\mathrm{k}}=$ luas permukaan semua shear key, $\mathrm{A}_{\mathrm{sm}}=$ luas permukaan yang bukan shear key, $\mathrm{f}_{\mathrm{ck}}=$ kuat tekan karakteristik beton, dan $\sigma_{n}=$ tegangan tekan sambungan .

Selain itu, juga terdapat rumus yang direkomendasikan berdasarkan ATEP, dalam Spanish Design Code. Rumus 11 ini bergantung pada total luas dari permukaan sambungan:

$$
V_{u}=A_{j}\left(1.14 \sigma_{n}+0.0564 \sqrt{f_{c d}}\right)
$$

dengan $\mathrm{V}_{\mathrm{u}}=$ gaya geser ultimit, $\mathrm{A}_{\mathrm{j}}=$ luas permukaan semua shear key, dan $\mathrm{f}_{\mathrm{cd}}=$ nilai kuat tekan beton .

Tahun 2006, Turmo membandingkan data hasil penelitiannya dengan kapasitas geser nominal berdasarkan metode AASHTO dan ATEP. Kemudian Turmo mengeluarkan formula baru berdasarkan rumus AASHTO yang menunjukkan hasil yang mendekati dengan eksperimennya. Rumus yang diusulkan oleh Turmo sebagai berikut:

$$
V_{n}=A_{k} \frac{\sqrt[3]{f_{c k}^{2}}}{100}\left(7 \sigma_{n}+33\right)+0.6 A_{s m} \sigma_{n}
$$

Pada tahun 2002, Rombach melakukan penelitian untuk menganalisa kekuatan geser dari multiple shear key pada kondisi dry joint menggunakan permodelan elemen hingga (finite element model) dan mengeluarkan formula lain dalam perhitungan kekuatan geser shear key yaitu dengan rumus 13 sebagai berikut:

$$
V_{n}=\frac{1}{\gamma_{F}}\left(\mu \cdot \sigma_{n} \cdot A_{\text {joint }}+f \cdot f_{c k} \cdot A_{k e y}\right)
$$

dengan $\gamma_{F}=$ koefisien keamanan, $\mu=$ koefisien friksi $\mathrm{A}_{\text {joint }}=$ luas daerah tekan, $\mathrm{f}=$ faktor lekukan pada shear key dan $\mathrm{A}_{\mathrm{key}}=$ luas permukaan semua key pada daerah yang gagal

Pada kapasitas geser dengan epoxy untuk shear key, hanya mengandalkan kuat friksinya sehingga persamaan kapasitas geser sebagai berikut:

$$
V_{n}=\frac{1}{\gamma_{F}} \cdot \mu \cdot \sigma_{n} \cdot A_{\text {joint }}
$$




\section{METODOLOGI PENELITIAN}

\section{Konsep perencanaan jembatan}

Perencanaan jembatan precast segmental box girder single cell ini sepanjang $300 \mathrm{~m}$ yang dibagi menjadi 5 bentang sama panjang. Dengan data perencanaan jembatan sebagai berikut:
- Panjang 1 bentang
$: 60 \mathrm{~m}$
- Panjang 1 segmen
$: 3 \mathrm{~m}$
- Bentang bersih jembatan : $57 \mathrm{~m}$
- Lebar total jembatan : $10 \mathrm{~m}$
- Lebar lantai kendaraan : $7 \mathrm{~m}$
- Jumlah lajur
: 2 lajur, 2 arah

Box girder ini direncanakan memiliki lebar $10 \mathrm{~m}$ dan tinggi $3.2 \mathrm{~m}$ dengan $\mathrm{f}_{\mathrm{c}}$ ' sebesar $50 \mathrm{MPa}$. Tendon direncanakan menggunakan strand jenis Uncoated Seven Wire Super Strands ASTM A-416-06 Grade 270 dan menggunakan angkur dari VSL yaitu Anchorage Type GC-Spiral Reinforcement dengan fy= $460 \mathrm{~N} / \mathrm{mm}^{2}$.

\section{Kerangka kerja}

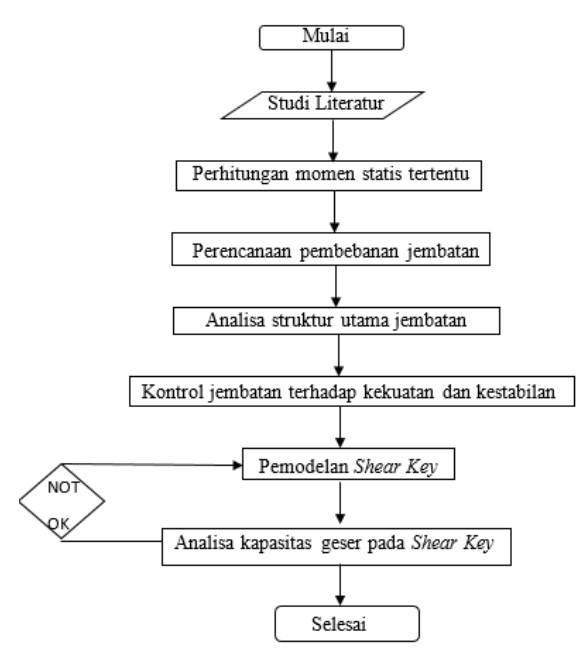

Gambar 5. Diagram Alir

\section{HASIL ANALISIS}

\section{Tegangan ijin bahan}

Beton memiliki tegangan ijin yang berbeda pada kondisi transfer dan kondisi servis sesuai dengan peraturan yang diijinkan.

- Pada kondisi transfer
○ $\bar{\sigma}_{\text {tekan }}\left(\mathrm{f}_{\mathrm{ct}}\right)$
$=28 \mathrm{MPa}$
- $\bar{\sigma}_{\text {tarik }}\left(f_{t t}\right)$
$=0 \mathrm{MPa}$

- Pada kondisi servis
$\circ \bar{\sigma}_{\text {tekan }}\left(f_{\text {cs }}\right)$
$=22.5 \mathrm{MPa}$
- $\bar{\sigma}_{\text {tarik }}\left(f_{t t}\right)$
$=0 \mathrm{MPa}$

- Modulus elastisitas beton

$\mathrm{E}=33234.0187 \mathrm{MPa}$

Tendon prategang juga memiliki tegangan tarik yang diijinkan sesuai dengan peraturan yang berlaku.

- Tegangan tarik ijin kabel (jacking) $\quad=1748.4 \mathrm{MPa}$

- Tegangan tarik ijin kabel (setelah pengangkuran) $=1488 \mathrm{MPa}$ 


\section{Analisa penampang box girder}

Tabel 1. Analisa Penampang Box Girder

\begin{tabular}{|c|c|c|c|c|c|c|}
\hline \multirow{2}{*}{$\begin{array}{c}\text { Luas } \\
\text { Penampang } \\
\left(\mathrm{mm}^{2}\right)\end{array}$} & \multicolumn{2}{|c|}{ Titik berat } & \multirow{2}{*}{$\begin{array}{c}\text { Inersia } \\
\left(\mathrm{mm}^{4}\right)\end{array}$} & \multirow{2}{*}{$\begin{array}{c}\text { Radius } \\
\text { Girasi }\left(\mathbf{r}^{2}\right)\end{array}$} & \multicolumn{2}{|c|}{ Kern } \\
\hline & $\mathbf{y}^{\mathrm{t}}$ & & & & $\mathbf{k}^{\mathrm{t}}(\mathbf{m m})$ & $\mathbf{k}^{\mathbf{b}}$ \\
\hline 6252110 & 1150.256 & 2049.744 & $8.36939 \times 10^{12}$ & 1338651.149 & 653.082 & 1163.786 \\
\hline
\end{tabular}

\section{Pembebanan}

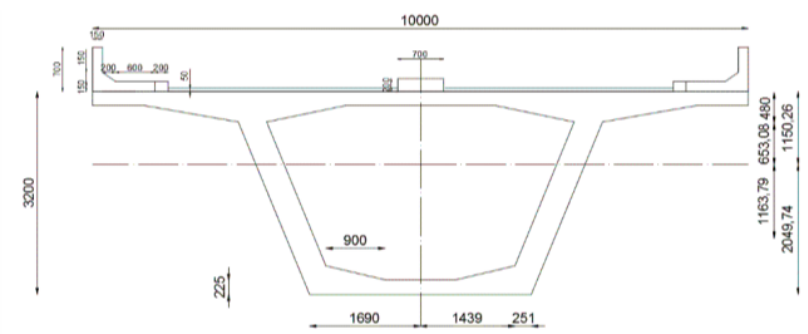

Gambar 6. Penampang box girder dan Struktur Sekunder

Tabel 2. Pembebanan pada Box Girder

\begin{tabular}{|c|c|c|c|}
\hline $\begin{array}{c}\text { Berat Sendiri } \\
\text { (DL) }\end{array}$ & 156.3028 & & $\mathrm{kN} / \mathrm{m}$ \\
\hline \multirow{3}{*}{$\begin{array}{l}\text { Beban Mati } \\
\text { Tambahan } \\
\text { (SDL) }\end{array}$} & Berat Aspal & 7.7 & $\mathrm{kN} / \mathrm{m}$ \\
\hline & $\begin{array}{c}\text { Berat } \\
\text { trotoar+kerb+railing }\end{array}$ & 11.88 & $\mathrm{kN} / \mathrm{m}$ \\
\hline & Berat median & 3.08 & $\mathrm{kN} / \mathrm{m}$ \\
\hline \multirow{2}{*}{$\begin{array}{l}\text { Beban Hidup } \\
\text { (LL) }\end{array}$} & Beban terbagi rata (UDL) & 48.0788 & $\mathrm{kN} / \mathrm{m}$ \\
\hline & Beban garis (KEL) & 343 & $\mathrm{kN}$ \\
\hline
\end{tabular}

\section{Kebutuhan tendon}

Perhitungan jumlah tendon menggunakan metode $\mathrm{C}$ line dan pada saat jembatan dalam kondisi servis.

- Mmaks $\left(\mathrm{M}_{\mathrm{z}}\right)=97095.0593 \mathrm{kNm}$

- $\mathrm{e}_{c}=653.0820 \mathrm{~mm}$

- e tendon $=1910.8195 \mathrm{~mm}$

$\bullet \mathrm{z}=2563.9015 \mathrm{~mm}$

- $\mathrm{F}_{\mathrm{S}} \quad=\frac{\mathrm{M}_{\mathrm{z}}}{\mathrm{z}}$

$$
=37870.0427 \mathrm{kN}
$$

- $\mathrm{n}$ strand $=242.3838$ strand

- 1 buah tendon terdiri dari 19 strand, sehingga total tendon yang dibutuhkan

$\mathrm{n}$ tendon $=\frac{242.3838}{19}$

$=12.7570 \sim 14$ tendon

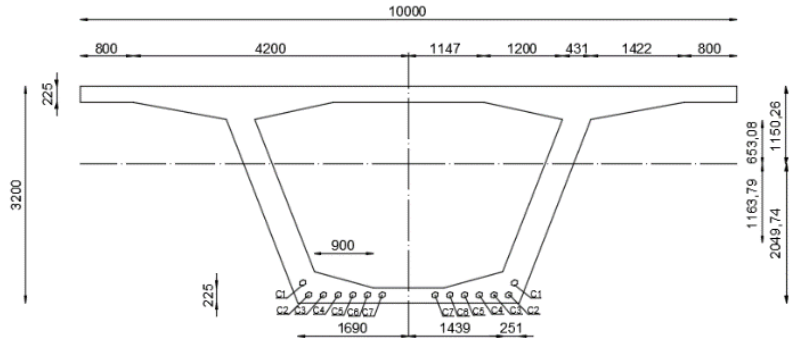

Gambar 7. Segmen Box Girder di Tengah Bentang 


\section{Kehilangan gaya prategang}

Tabel 3. Kehilangan Gaya Prategang Sepanjang Bentang

\begin{tabular}{ccccccc}
\hline $\begin{array}{c}\text { Jarak } \\
(\mathbf{m})\end{array}$ & Gesekan & $\begin{array}{c}\text { Slip } \\
\text { Angkur }\end{array}$ & $\begin{array}{c}\text { Perpendekan } \\
\text { Elastis }\end{array}$ & Rangkak & Susut & $\begin{array}{c}\text { Relaksasi } \\
\text { Baja }\end{array}$ \\
\hline 0 & $77.92 \%$ & $75.57 \%$ & $74.79 \%$ & $73.64 \%$ & $71.07 \%$ & $67.48 \%$ \\
\hline 3 & $77.74 \%$ & $75.75 \%$ & $74.99 \%$ & $73.68 \%$ & $71.11 \%$ & $67.52 \%$ \\
\hline 6 & $77.56 \%$ & $75.93 \%$ & $75.21 \%$ & $74.03 \%$ & $71.47 \%$ & $67.88 \%$ \\
\hline 9 & $77.38 \%$ & $76.11 \%$ & $75.37 \%$ & $73.84 \%$ & $71.28 \%$ & $67.69 \%$ \\
\hline 12 & $77.20 \%$ & $76.29 \%$ & $75.47 \%$ & $73.31 \%$ & $70.74 \%$ & $67.15 \%$ \\
\hline 15 & $77.01 \%$ & $76.47 \%$ & $75.49 \%$ & $72.54 \%$ & $69.98 \%$ & $66.39 \%$ \\
\hline 18 & $76.83 \%$ & $76.65 \%$ & $75.46 \%$ & $71.61 \%$ & $69.04 \%$ & $65.45 \%$ \\
\hline 21 & $76.65 \%$ & $76.65 \%$ & $75.18 \%$ & $70.38 \%$ & $67.81 \%$ & $64.22 \%$ \\
\hline 24 & $76.47 \%$ & $76.47 \%$ & $74.71 \%$ & $69.07 \%$ & $66.50 \%$ & $62.92 \%$ \\
\hline 27 & $76.29 \%$ & $76.29 \%$ & $74.26 \%$ & $67.94 \%$ & $65.38 \%$ & $61.79 \%$ \\
\hline 28.5 & $76.20 \%$ & $76.20 \%$ & $73.56 \%$ & $66.16 \%$ & $63.59 \%$ & $60.00 \%$ \\
\hline 30 & $76.29 \%$ & $76.29 \%$ & $74.26 \%$ & $67.94 \%$ & $65.38 \%$ & $61.79 \%$ \\
\hline 33 & $76.47 \%$ & $76.47 \%$ & $74.71 \%$ & $69.07 \%$ & $66.50 \%$ & $62.92 \%$ \\
\hline 36 & $76.65 \%$ & $76.65 \%$ & $75.18 \%$ & $70.38 \%$ & $67.81 \%$ & $64.22 \%$ \\
\hline 39 & $76.83 \%$ & $76.65 \%$ & $75.46 \%$ & $71.61 \%$ & $69.04 \%$ & $65.45 \%$ \\
\hline 42 & $77.01 \%$ & $76.47 \%$ & $75.49 \%$ & $72.54 \%$ & $69.98 \%$ & $66.39 \%$ \\
\hline 45 & $77.20 \%$ & $76.29 \%$ & $75.47 \%$ & $73.31 \%$ & $70.74 \%$ & $67.15 \%$ \\
\hline 48 & $77.38 \%$ & $76.11 \%$ & $75.37 \%$ & $73.84 \%$ & $71.28 \%$ & $67.69 \%$ \\
\hline 51 & $77.56 \%$ & $75.93 \%$ & $75.21 \%$ & $74.03 \%$ & $71.47 \%$ & $67.88 \%$ \\
\hline 54 & $77.74 \%$ & $75.75 \%$ & $74.99 \%$ & $73.68 \%$ & $71.11 \%$ & $67.52 \%$ \\
\hline 57 & $77.92 \%$ & $75.57 \%$ & $74.79 \%$ & $73.64 \%$ & $71.07 \%$ & $67.48 \%$ \\
\hline & & & & & &
\end{tabular}

\section{Shear key box girder}

Perencanaan shear key dilakukan pada posisi sambungan geser antara segmen box girder pertama dan kedua karena gaya geser terbesar terjadi dekat dengan tumpuan. Untuk analisis shear key, dilakukan pada sambungan antara segmen 1 dan segmen 2 sejarak $3 \mathrm{~m}$ dari tepi jembatan.

$\mathrm{Vu} \quad=8454.0478 \mathrm{kN}$

$\mathrm{Vp} \quad=6484.3768 \mathrm{kN}$

Gaya geser akibat beban luar dan tendon $\quad=\mathrm{Vu}-\phi \mathrm{Vp}$

$=3590.7652 \mathrm{kN}$

Shear key didesain pada bagian web dari box girder sehingga gaya geser yang bekerja pada titik berat penampang ditransfer ke masing-masing web. Gaya geser pada web selanjutnya dibagi ke masing-masing shear key yang menahan gaya geser. Posisi shear key pada web box girder seperti pada gambar 8 dibawah ini.

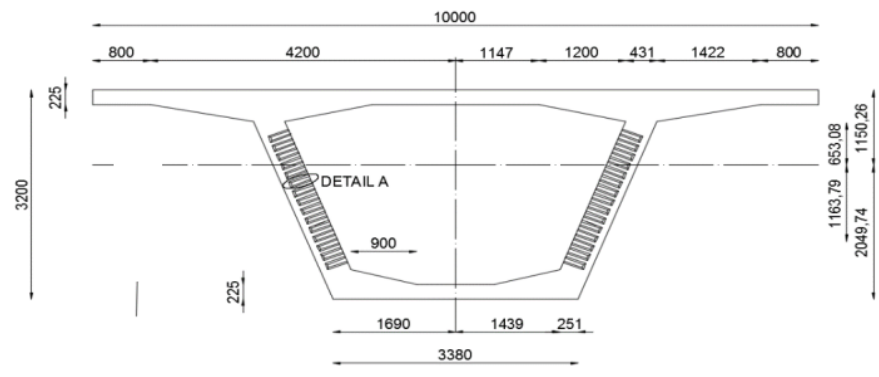

Gambar 8. Posisi Shear Key pada Web Box Girder 
Jumlah shear key dalam 1 sisi web box girder sebanyak 16 buah. Pada segmen ini terdapat tendon yang terletak pada shear key sehingga jumlah shear key yang bekerja secara efektif sebanyak 10 buah. Gaya geser yang bekerja pada web box girder tersebut akan dibagi sama rata pada masing-masing shear key.

Vu 1 shear key $=\frac{1936.3825}{10}$

$$
=193.6383 \mathrm{kN}
$$

Shear key direncanakan dalam 2 bentuk yang berbeda yaitu single shear key dan multiple shear key dengan bentuk seperti pada gambar 9 dibawah ini. Setiap bentuk juga direncakan variasi ukuran dan sudut untuk diketahui kapasitas gesernya sesuai dengan tabel 4 di bawah.
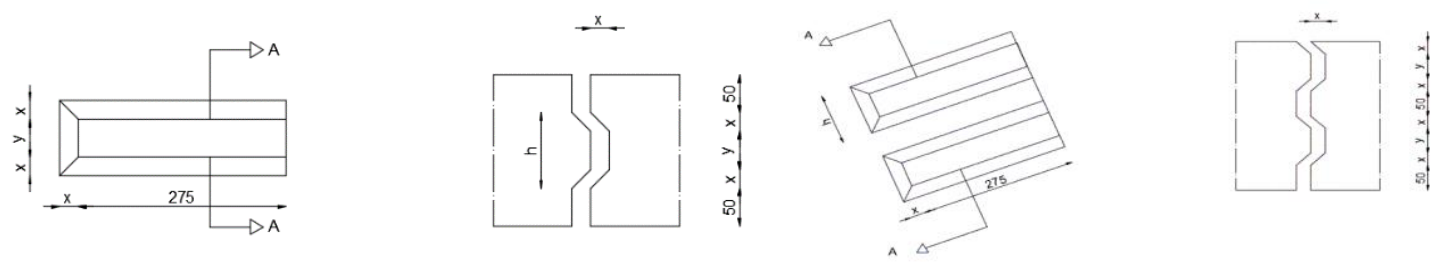

Gambar 9. Single Shear Key dan Multiple Shear Key

Tabel 4. Variasi Dimensi Shear Key

\begin{tabular}{ccccc}
\hline Sudut & $\mathbf{h}(\mathbf{m m})$ & $\mathbf{x}(\mathbf{m m})$ & $\mathbf{y}(\mathbf{m m})$ & $\begin{array}{c}\mathbf{b}_{\mathbf{n}} \\
(\mathbf{m m})\end{array}$ \\
\hline 45 & 100 & 31.3 & 37.5 & 306.3 \\
\hline 60 & 100 & 54.1 & 37.5 & 329.1 \\
\hline 45 & 100 & 25.0 & 50 & 300.0 \\
\hline 60 & 100 & 43.3 & 50 & 318.3 \\
\hline 45 & 100 & 18.8 & 62.5 & 293.8 \\
\hline 60 & 100 & 32.5 & 62.5 & 307.5 \\
\hline
\end{tabular}

Kapasitas geser untuk shear key sambungan kering dihitung menggunakan metode AASHTO, ATEP, Turmo dan Rombach. Hasil perhitungan kapasitas geser nominal untuk single shear key dan multiple shear key ditampilkan pada tabel 5dan 6 di bawah ini.

Tabel 5. Kapasitas Geser Single Shear Key Sambungan Kering

\begin{tabular}{cccccccc}
\hline \multirow{2}{*}{ Sudut } & \multirow{2}{*}{\begin{tabular}{c}
$\mathbf{m}$ \\
\cline { 3 - 7 }
\end{tabular}} & AASHTO & ATEP & Turmo & Rombach & $\begin{array}{c}\text { Vn rata- } \\
\text { rata } \\
(\mathbf{k N})\end{array}$ & $\begin{array}{l}\boldsymbol{\phi V n} \\
(\mathbf{k N})\end{array}$ \\
\hline 45 & 37.5 & 522.378 & 338.170 & 338.351 & 197.080 & 348.995 & 261.746 \\
\hline 60 & 37.5 & 558.097 & 359.965 & 361.459 & 204.186 & 370.927 & 278.195 \\
\hline 45 & 50 & 512.550 & 332.143 & 331.993 & 195.142 & 342.957 & 257.218 \\
\hline 60 & 50 & 541.244 & 349.703 & 350.557 & 200.822 & 360.581 & 270.436 \\
\hline 45 & 62.5 & 502.693 & 326.085 & 325.614 & 193.205 & 336.899 & 252.674 \\
\hline 60 & 62.5 & 524.302 & 339.349 & 339.596 & 197.461 & 350.177 & 262.633 \\
\hline
\end{tabular}

Tabel 6. Kapasitas Geser Multiple Shear Key Sambungan Kering

\begin{tabular}{cccccccc}
\hline \multirow{2}{*}{ Sudut } & $\mathbf{y}(\mathbf{m m})$ & \multicolumn{4}{c}{$\mathbf{V n}(\mathbf{k N})$} & \multicolumn{2}{c}{$\begin{array}{c}\text { Vn rata- } \\
\text { rata }(\mathbf{k N})\end{array}$} \\
\cline { 3 - 6 } & & AASHTO & ATEP & Turmo & Rombach & \\
\hline 45 & 37.5 & 639.296 & 338.170 & 455.269 & 239.342 & 418.020 & 313.515 \\
\hline 60 & 37.5 & 664.447 & 359.965 & 467.809 & 246.025 & 434.562 & 325.921 \\
\hline 45 & 50 & 632.393 & 332.143 & 451.835 & 230.959 & 411.833 & 308.874 \\
\hline 60 & 50 & 652.568 & 349.703 & 461.881 & 235.897 & 425.012 & 318.759 \\
\hline 45 & 62.5 & 625.476 & 326.085 & 448.398 & 217.228 & 404.297 & 303.222 \\
\hline 60 & 62.5 & 640.649 & 339.349 & 455.943 & 220.362 & 414.076 & 310.557 \\
\hline
\end{tabular}

Hasil perhitungan kapasitas geser nominal dari single shear key dan multiple shear key ditampilkan dalam bentuk grafik pada gambar 10 sampai 13 di bawah ini. 


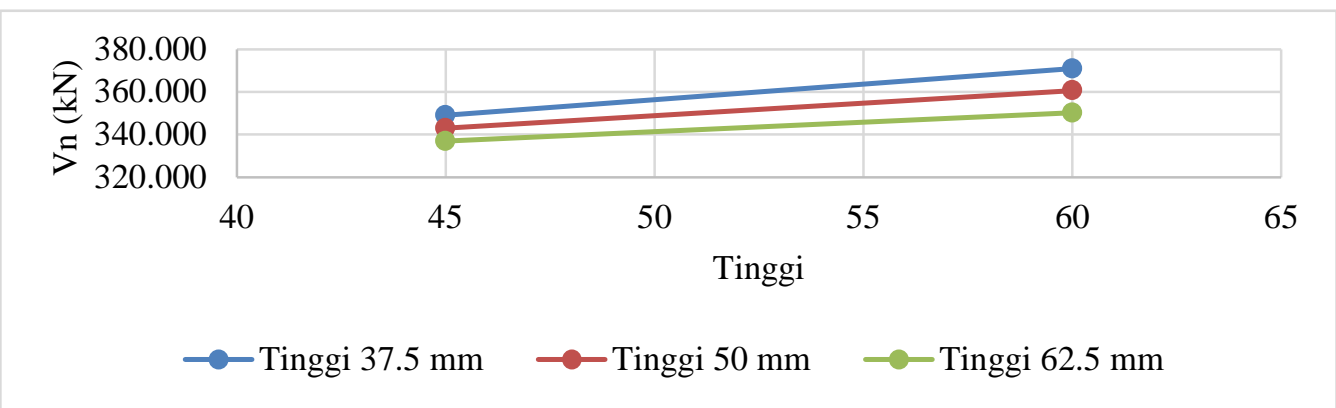

Gambar 10. Grafik Pengaruh Sudut Terhadap Vn Single Shear Key Sambungan Kering

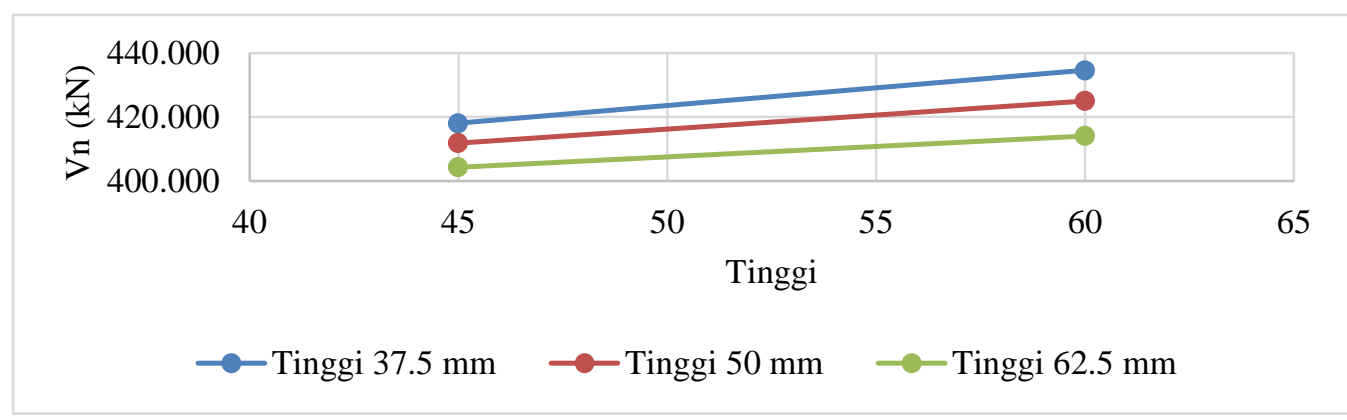

Gambar 11. Grafik Pengaruh Sudut Terhadap Vn Multiple Shear Key Sambungan Kering

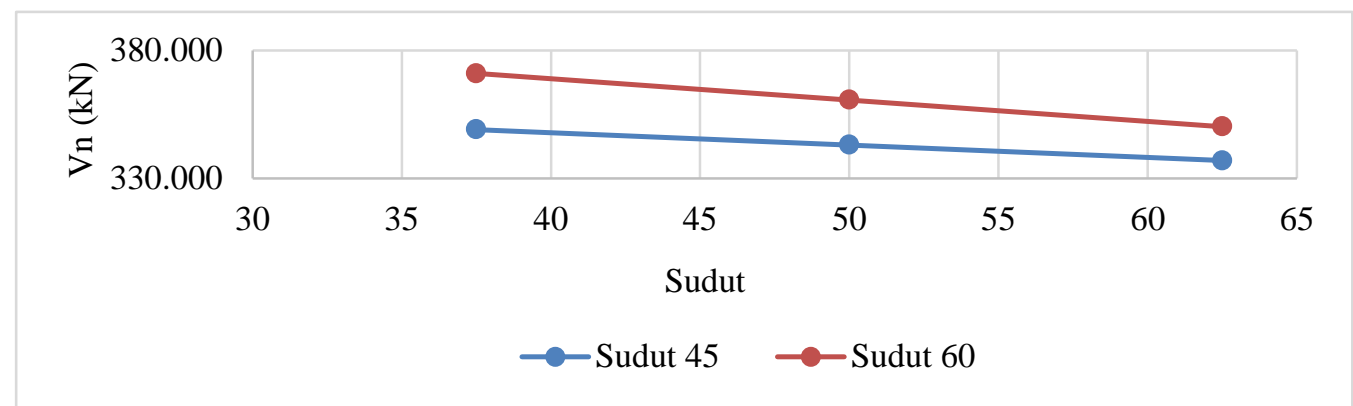

Gambar 12. Grafik Pengaruh Tinggi Terhadap Vn Single Shear Key Sambungan Kering

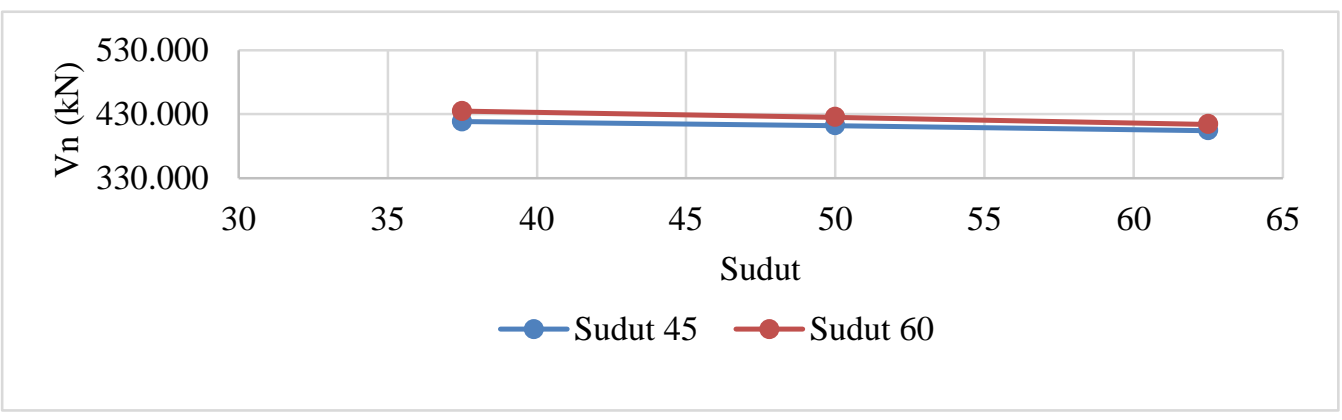

Gambar 13. Grafik Pengaruh Tinggi Terhadap Vn Multiple Shear Key Sambungan Kering

Kapasitas geser nominal pada saat web box girder tidak ada shear key serta tidak diberikan epoxy sebagai berikut. $\phi \mathrm{V}_{\mathrm{n}}=1936.383 \mathrm{kN}$

Saat sambungan tanpa shear key diberikan epoxy terjadi pengurangan kapasitas geser pada web box girder. Kapasitas geser flat key dengan epoxy sebagai berikut. 


$$
\begin{aligned}
\varnothing V_{n} & =0.75 \cdot \frac{1}{\gamma_{F}} \cdot \mu \cdot \sigma_{n} \cdot A_{\text {joint }} \\
& =1832.1400 \mathrm{kN}
\end{aligned}
$$

\section{KESIMPULAN}

Berdasarkan hasil analisis, maka dapat disimpulkan:

1. Kapasitas geser nominal dengan shear key lebih besar $20.9042 \%$ daripada kapasitas geser nominal tanpa menggunakan shear key meskipun telah diberikan epoxy.

2. Analisis numerik menggunakan metode AASHTO, Turmo dan Rombach menunjukkan peningkatan kapasitas geser nominal sebesar $17.9921 \%$, 25.3021\%, dan $14.5283 \%$ dari single shear key menjadi multiple shear key. Sedangkan untuk metode ATEP tidak diperoleh adanya perbedaan kapasitas geser nominal antara single shear key dan multiple shear key karena metode ini hanya memperhitungkan luas permukaan bidang shear key.

3. Untuk tinggi shear key yang sama, semakin besar sudut shear key semakin tinggi kapasitas geser nominal.

4. Untuk sudut shear key yang sama, semakin tinggi shear key semakin kecil kapasitas gesernya.

\section{DAFTAR PUSTAKA}

AASHTO. (1999). Guide Specifications for Design and Construction of Segmental Concrete Bridges. American Association of State Highway and Transportation Officials, Washington.

ASTM A 416. Standard Specification for Steel Strand, Uncoated Seven-Wire for Prestressed Concrete.

ATEP. (1996). Proyecto y construccionn de puentes y estructuras con pretensado exterior. Colegio de Ingenieros de Caminos, Madrid.

Badan Standardisasi Nasional. (2004). Perencanaan Struktur Beton Untuk Jembatan. RSNI T-12-2004. BSN, Jakarta.

Badan Standardisasi Nasional. (2013). Persyaratan Beton Struktural untuk Bangunan Gedung (SNI 2847:2013). Badan Litbang Departemen Pekerjaan Umum Republik Indonesia, Jakarta.

Badan Standardisasi Nasional. (2008). Standar Pembebanan untuk Jembatan (SNI 1725:2016). Badan Litbang Departemen Pekerjaan Umum Republik Indonesia, Jakarta.

Koseki, K., dan Breen, J. E. (1983). Exploratory Study of Shear Strength of Joint for Precast Segmental Bridges. The Universitas Texas Austin, Texas..

Nawy, E. G., Hardani, dan Hardani, H.W. (2001). Beton Prategang Suatu Pendekatan Mendasar, Volume 1 Edisi ke 3. Erlangga, Jakarta.

Podolny JR, Walter dan Muller, Jean.M. (1982). Construction and Design of Prestressed Concrete Segmental Bridges. John Wiley and Sons, Inc., New York.

Rombach, G. (2002). "Precast Segmental Box Girder Bridges with External Prestressing Design and Construction". Technical University of Hamburg, Hamburg.

Sullivan, S. R. (2003)“Behavior of Transverse Joint in Precast Deck Panel System, MSc. Thesis". College of Engineering and Technology of Ohio University, Ohio.

Turmo, J., Ramos, G. dan Aparicio, A. C. (2006). "Shear Strength of Match Cast Dry Joints of Precast Concrete Segmental Bridges: Proposal for Eurocode 2". Materiales de Construcción.

U.S. Department of Transportation. (2016). Post-Tensioned Box Girder Design Manual. Federal Highway Administration, Washington. 